\title{
Chemical composition and biological activities of essential oils from the leaves of Cymbopogon giganteus Chiov. and Cymbopogon schoenanthus (L.) Spreng (Poaceae) from Benin
}

\author{
Guy Alain ALITONOU ${ }^{1}$, Félicien AVLESSI ${ }^{1}$, Fidele TCHOBO ${ }^{1}$, \\ Jean-Pierre NOUDOGBESSI ${ }^{1}$, Aretas TONOUHEWA ${ }^{1}$, Boniface YEHOUENOU ${ }^{1}$, \\ Chantal MENUT $^{2}$ and Dominique K. SOHOUNHLOUE ${ }^{1 *}$ \\ ${ }^{1}$ Laboratoire d'Etude et de Recherche en Chimie Appliquée. BP : 2009 Ecole Polytechnique d'Abomey-Calavi, \\ Université d'Abomey-Calavi, Bénin. \\ ${ }^{2}$ Institut des Biomolécules Max Mousseron, IBMM UMR 5247 CNRS-UM1-UM2, ENSCM, 8 rue de l'Ecole \\ Normale, 34296, Montpellier cedex 5, France. \\ *Corresponding author, E-mail: alainguy20022002@yahoo.fr
}

\begin{abstract}
The chemical composition of essential oils obtained from the leaves of Cymbopogon giganteus Chiov. and Cymbopogon schoenanthus (L.) Spreng, two Poaceae growing wild in Benin were analyzed by GC and GC/MS. The main constituents of Cymbopogon giganteus were cis-p-mentha-1(7),8-dien-2-ol (19.4\%), transp-mentha-2,8-dien-1-ol (16.4\%) and limonene (13.7\%). The major components identified in the oil of Cymbopogon schoenanthus were piperitone $(68.4 \%)$, and $\delta$-2-carene $(11.5 \%)$. The antimicrobial activity of the essential oil of Cymbopogon giganteus was found to be moderate on Staphylococcus aureus ATCC 25923 with MIC equal to $0.32 \pm 0.02 \mathrm{mg} / \mathrm{mL}$ and Escherichia coli ATCC 25922 with MIC equal to $0.64 \pm 0.34 \mathrm{mg} / \mathrm{mL}$. This same oil induced the death of $57.84 \%$ of ticks at $8 \mu \mathrm{L}$. Therefore, essential oil of Cymbopogon schoenanthus had a low antimicrobial activity on Staphylococcus aureus ATCC 25923 with MIC equal to 2.63 $\pm 0.16 \mathrm{mg} / \mathrm{mL}$ and Escherichia coli ATCC 25922 with MIC equal to $2.63 \pm 0.16 \mathrm{mg} / \mathrm{mL}$.

(C) 2012 International Formulae Group. All rights reserved.
\end{abstract}

Keywords: Essential oils, Cymbopogon giganteus Chiov., Cymbopogon schoenanthus (L.) Spreng, antimicrobial and acaricidal activities.

\section{INTRODUCTION}

Cymbopogon giganteus and Cymbopogon schoenanthus are West African endemic species of plants belonging to Poaceae family. Cymbopogon giganteus is used against mental illness and bronchopulmonary affections (Alitonou et al., 2006), pain from scorpions bite (Fortin et al., 1990). The same plants are used for febrifuge, pulmonary, antiicteric disinfectants and antimalarial properties (Menut et al., 2000), and also against bilharziose, jaundice, cold, conjunctivitis, migraine, dermatoses, rheumatic pains, childhood coughs and hepatitises (Alitonou, 2006). This species showed strong effect against chloroquine resistant Plasmodium (Kimbi and FagbenroBeyioku, 1996). Cymbopogon schoenanthus 
is used for the treatment of madness in Africa and in Ethiopia (Akoegninou et al., 2006).

Studies were already carried out on Cymbopogon giganteus species. Only the more recent studies, especially relating to essential oils of the leaves, will be cited here. Several chemotypes of the essential oil of Cymbopogon giganteus have been reported according to the major compounds and their distribution: limonene $(17.3 \%)$, trans-pmentha-1(7),8-dien-2-ol (17\%), cis-p-mentha1(7),8-dien-2-ol (16.5\%), trans-p-mentha-2,8dièn-1-ol (13.8\%) and cis-p-mentha-2,8-dien1-ol (9.3\%). The cis-isopiperitenol (4.5\%) and carvone $(4.1 \%)$ are also present at considerable amounts (Menut et al., 2000) as well as trans and cis-p-mentha-1(7),8-dien-2ols (24.0-35.2\% and 16.0-24.0\%), trans and cis-p-mentha-2,8-dien-1-ols (13.3-16.2\% and $8.2-10.2 \%)$. We note the presence of limonene with variable proportions $(0.5-13.2 \%)$, pmethylacetophenone (3.2-6.0\%) and carvone (0.1-2.9\%) (Sidibe et al., 2001); trans-pmentha-2,8-dien-1-ol (20.7\%), trans-pmentha-1(7),8-dien-2-ol (19.6\%), cis-pmentha-1(7),8-dièn-2-ol $\quad(19.0 \%), \quad$ cis-pmentha-2,8-dièn-1-ol (9.2\%) and limonene (5.1\%) (Kanko et al., 2004); trans-p-1(7),8menthadien-2-ols (22.3\%), cis-p-1(7),8menthadien-2-ols (19.9\%), trans-p-2,8menthadien-1-ols (14.3\%) and cis-p-2,8menthadien-1-ols (10.1\%) (Alitonou et al., 2006); limonène $\quad(23 \%)$, cis- $p$-mentha-2,8dien-1-ol (14.3\%) and trans-p-mentha-2,8dien-1-ol (5.6\%) (Nyamador et al., 2010); pmenthadienols (44\%) and limonene (42\%) (Bassolé et al., 2011). The reports have shown that Cymbopogon schoenanthus is rich in piperitone $(68 \%)$ and carene-2 $(16.48 \%)$ (Koba et al., 2003); cis-p-menth-2-en-1-ol (18.6\%), trans-p-ment-2-en-1-ol (9.5\%), elemol (7.4\%), cis-piperitol (7.2\%) and limonene (7.0\%) (Bouchikhi et al., 2010).

These oils also have some biological activities: antimicrobial and antifungal (Koba et al., 2003; Bassolé et al., 2011) ; insecticide (Ketoh et al., 2006; Bouchikhi et al., 2010;
Nyamador et al., 2010), larvicide (Ketoh et al., 2006); anti-inflammatory and antiradical (Menut et al., 2000; Sahouo et al., 2003; Alitonou et al., 2006).

We have previously reported the chemical composition of the volatile constituents of two species of Cymbopogon species from Benin. This study was carried out in order to evaluate the chemical composition and investigate on the antimicrobial and acaricide properties of essential oils of Cymbopogon giganteus and Cymbopogon schoenanthus samples collected in two different areas of Benin.

\section{MATERIALS AND METHODS \\ Plants material}

Fresh leaves of Cymbopogon giganteus and Cymbopogon schoenanthus were collected in two areas of Benin, at Houintopka (Mono) (Sample C. g.) and Djougou (Donga) (Sample C. s.) in May 2012. Voucher specimens [AA6419/HNB] and [AA6420/HNB] respectively were deposited in the Herbarium of the University of Abomey-Calavi, Department of Vegetal Biology.

\section{Essential oils isolation}

The essential oils were obtained from the air-dried leaves by hydrodistillation for $2 \mathrm{~h}$ rs using a Clevenger-type apparatus. The oil was collected, dried over anhydrous sodium sulphate and stored in sealed vials below 10 ${ }^{\circ} \mathrm{C}$ until required for analyses.

\section{GC and GC-MS analyses}

Quantitative and qualitative analyses of the essential oils were carried out by gas chromatography/flame ionization detection (GC/FID) and gas chromatography/mass spectrometry (GC/MS).

GC/FID analyses were performed using a Varian CP-3380 GC equipped with a DB1 (100\% dimethylpolysiloxane) fitted with a fused silica capillary column $(30 \mathrm{~m} \times 0.25$ $\mathrm{mm}$, film thickness $0.25 \mu \mathrm{m}$ ) and Supelcowax 10 (polyethylene glycol) fused capillary 
column $(30 \mathrm{~m} \times 0.25 \mathrm{~mm}$, film thickness 0.25 $\mu \mathrm{m})$; temperature program $50{ }^{\circ}-200{ }^{\circ} \mathrm{C}$ at 5 ${ }^{\circ} \mathrm{C} / \mathrm{min}$, injector temperature $220{ }^{\circ} \mathrm{C}$, detector temperature $250{ }^{\circ} \mathrm{C}$, carrier gas $\mathrm{N}_{2}$ at a flow rate of $0.5 \mathrm{~mL} \cdot \mathrm{min}^{-1}$. Diluted samples $(10 / 100$, $\mathrm{v} / \mathrm{v}$, in methylene chloride) of $2.0 \mu \mathrm{L}$ were injected manually in a split mode (1/100). The percentage compositions were obtained from electronic integration measurements without taking into account relative response factors. The linear retention indices of the components were determined relatively to the retention times of a series of n-alkanes $\left(\mathrm{C}_{9}-\mathrm{C}_{20}\right)$.

GC/MS analyses were performed using a Hewlett Packard apparatus equipped with a HP1 fused silica column $(30 \mathrm{~m} \times 0.25 \mathrm{~mm}$, film thickness $0.25 \mu \mathrm{m}$ ) and interfaced with a quadruple detector (Model 5970). Column temperature was programmed from $70^{\circ}$ to $200{ }^{\circ} \mathrm{C}$ at $10{ }^{\circ} \mathrm{C} / \mathrm{min}$; injector temperature was $220{ }^{\circ} \mathrm{C}$. Helium was used as carrier gas at a flow rate of $0.6 \mathrm{~mL} \cdot \mathrm{min}^{-1}$, the mass spectrometer was operated at $70 \mathrm{eV} .2 .0 \mu \mathrm{L}$ of diluted samples $(10 / 100, \mathrm{v} / \mathrm{v}$, in methylene chloride) were injected manually in the split mode (1/100).

The identification of individual compounds was based on the comparison of their relative retention times with those of standard samples on the DB1 column and by matching the linear retention indices and mass spectra of peaks with those obtained from authentic samples and/or the NBS75K.L and NIST98.L libraries and published data (Adams, 2007; Joulain et König, 1998).

\section{Antibacterial activity \\ Essential oil emulsion}

Two milliliters of Mueller Hinton broth and $0.02 \mathrm{~g} / \mathrm{L}(\mathrm{w} / \mathrm{v})$ of phenol red were added $40 \mu \mathrm{L}$ of essential oil and 2 drops of Tween 80 , introduced in an hemolyse test tube and homogenized.

\section{Preparation of bacteria suspensions}

Bacteria preparations were prepared from the stocks of the three bacteria tested. A pure colony of each stock was suspended in 5 $\mathrm{mL}$ of Mueller Hinton Broth. After incubation at $37{ }^{\circ} \mathrm{C}$ for 2 hours, we obtained a turbidity of $10^{6} \mathrm{cfu} / \mathrm{mL}$ corresponding to the scale 2 of McFarland standard.

\section{Determination of Minimum Inhibitory Concentrations (MIC)}

The method used the one described by Yehouenou et al. (2010a, b). $100 \mu \mathrm{L}$ of bubble Mueller Hinton broth containing phenol red at $0.02 \mathrm{~g} / \mathrm{L}$ were introduced in each well of 96 wells microplate. $100 \mu \mathrm{L}$ of essential oil emulsion (initial solution) were added in the wells of the first column except that of the second line and a serial two fold dilution was performed to obtain final concentration range. $100 \mu \mathrm{L}$ of Mueller Hinton not containing phenol red were introduced in the first well of the first columns and a serial two fold dilution was performed as before. All the wells of the second column received $100 \mu \mathrm{L}$ of bacteria suspension except the first and second lines, the negative and positive control respectively. The microplate was covered with parafilm and incubated at $37{ }^{\circ} \mathrm{C}$ for approximately 18 hours.

\section{Determination of Minimum Bactericidal Concentrations (MBCs)}

MBCs were appreciated by method proposed by Oussou et al. (2004), also used by Kpadonou et al. (2012). Each well of the microtiter-plate received $50 \mu \mathrm{L}$ of mixture of essential oil and the strain. The strain was isolated on sterile MHA (Mueller Hinton Agar) cultured in Petri dishes. These plates were incubated at $37{ }^{\circ} \mathrm{C}$ for $24 \mathrm{~h}$. The MBC is the lowest concentration of essential oil at which $99.9 \%$ of the microorganisms are killed. The tests were carried out in triplicate.

\section{Acaricide activity}

The harvest of the ticks was carried out as described by Pamo et al. (2003). The ticks were brought to the laboratory, in plastic Petri dish perforated by four small air pockets surroundings of $1 \mathrm{~mm}$ of diameter (for airing) from where they were identified with the binocular magnifying glass thanks to the key 
of Walker et al. (2002) and selected according to their size $(4.2 \pm 0.4) \mathrm{mm}$ and weight $(0.05$ $\pm 0.01) \mathrm{g}$ for their use for the tests. The sensitivity test consisted in putting a definite number of adult ticks (10) in different Petri dish. To varied amount of essential oil were added a variable essential oil amount $(1 \mu \mathrm{L}$, $2 \mu, 4 \mu \mathrm{L}, 6 \mu \mathrm{L}$ and $8 \mu \mathrm{L})$. A conrol was performed under the same experimental conditions and the petri dish did not receive essential oil under the same experimental conditions or Petri dish did not receive any essential oil amount. The number of ticks dead was counted after $6 \mathrm{~h}$. The experiment was carried out 3 times. The death rate was calculated by using the expression of Abbott (1925).

Mo $=$ mortality recorded in the treated batches $(\%) ; \mathrm{Me}=$ mortality recorded at the witnesses $(\%) ; \mathrm{Mc}=$ corrected mortality $(\%)$.

$M c=\frac{M o-M e}{100-M g} \times 100$

\section{Statistical analysis}

Data were subjected to analysis of variance (ANOVA). They were expressed as the mean \pm standard error of mean of triplicate measurements; standard deviations did not exceed $5 \%$.

\section{RESULTS AND DISCUSSION}

Chemical composition of essential oils obtained from fresh leaves of two Poaceae from Benin

Hydrodistillation of the air-dried leaves of Cymbopogon giganteus and Cymbopogon schoenanthus gave oil yield of $0.91 \%(\mathrm{w} / \mathrm{w})$ and $3.49 \% \quad(\mathrm{w} / \mathrm{w})$ respectively. The compounds identified in the essential oils of Cymbopogon giganteus and Cymbopogon schoenanthus are listed in Table 1. A total of 27 and 30 compounds representing $95.3 \%$ and $98.3 \%$ of the oils were identified in the essential oils of Cymbopogon giganteus and
Cymbopogon schoenanthus respectively. The major constituents of Cymbopogon giganteus oil were cis-p-mentha-1(7),8-dien-2-ol (19.4\%), trans-p-mentha-2,8-dien-1-ol $(16.4 \%)$ and limonene (13.7\%). This composition is similar to those obtained in previously works (Sidibé et al., 2001; Sahouo et al., 2003; Alitonou et al., 2006). The main constituents in Cymbopogon schoenanthus essential oil were piperitone $(68.4 \%), \delta$-2carene $(11.5 \%)$. All of samples were characterized by high percentage of oxygenated monoterpenes.

\section{Antibacterial activity}

Two microbial stocks were used in the present study. The Minimum Inhibitory Concentration (MIC) values were determined for all. The essential oil of the leaves of $C$. giganteus showed a very interesting antimicrobial activity against Staphylococcus aureus ATCC 25923 (MIC $=0.32 \pm 0.02$ $\mathrm{mg} / \mathrm{mL}$ ) and Escherichia coli ATCC 25922 ( $\mathrm{MIC}=0.64 \pm 0.34 \mathrm{mg} / \mathrm{mL})$. C. schoenanthus showed an average activity against the same microbial agent with the MIC $=2.63 \pm 0.16$ $\mathrm{mg} / \mathrm{mL}$ for Staphylococcus aureus, MIC = $(2.63 \pm 0.16) \mathrm{mg} / \mathrm{mL}$ respectively (Table 2$)$.

The Minimum Bactericidal Concentration (MBC) values were determined for the essential oil of $C$. giganteus on Escherichia coli ATCC 25922 with MBC equal to $2.56 \pm 0.15 \mathrm{mg} / \mathrm{mL}$ and on Staphylococcus aureus ATCC 25923 with $\mathrm{MBC}$ equal to $1.32 \pm 0.08 \mathrm{mg} / \mathrm{mL}$ (Table 2).

The essential oil of $C$. giganteus was more active than that of $C$. schoenanthus on the two microbial strains used. It should be also noted that the oil of $C$. giganteus was bactericidal on $E$. coli with an antibiotic capacity $(\mathrm{MBC} / \mathrm{MIC})=4$ and bacteriostatic on $S$. aureus with an antibiotic capacity $(\mathrm{MBC} / \mathrm{MIC})>4$ (Kpadonou et al., 2012).

The antimicrobial activities have been mainly explained through the presence of 
oxygenated sesquiterpenes and monoterpenes. The synergistic effect of essential oil components is a promising field that could lead to the optimization of a given bioactivity.

On the contrary C. schoenanthus displayed a low antimicrobial activity against the two strains relating to the absence of its antibiotic capacity against these latters. This fact may be due to the essential oil composition.

\section{Acaricidal activity}

The analysis of the results shows a variability of the death rate of Amblyomma variegatum, according to the essential oil amount of $C$. giganteus. After six hours, the death rate is high, what shows that the essential oil of $C$. giganteus has an action on these parasites. This activity was observed starting from the amount of $2 \mu \mathrm{L}$, became interesting (> 50\%) starting from amount of 4 $\mu \mathrm{L}$ by inducing the death of $57.84 \%$ of ticks, and reached the maximum at the strongest amount of $8 \mu \mathrm{L}$. We can conclude that the essential oil of $C$. giganteus has an insecticidal activity on Amblyomma variegatum ticks. Our results confirm those obtained by Nyamador et al. (2010) in Togo.

On the other hand, with the essential oil of C. schoenanthus, we observed no effect on Amblyomma variegatum for the amounts of 2 , 4 , and $6 \mu \mathrm{L}$ while a small percentage of death rate was noted for the maximum quantity of 8 $\mu \mathrm{L}$. Our results are in contradiction with those obtained by Bouchiki et al. (2010) in Tunisia on two harmful insects. This contradiction can be allotted to the physiology of the insects or to the chemical composition of essential oil. The essential oil of $C$. schoenanthus of Tunisia, rich in para-menth-2-en-1-ol and was devoid of piperitone whereas our own was mainly constituted of piperitone (Figure 1).

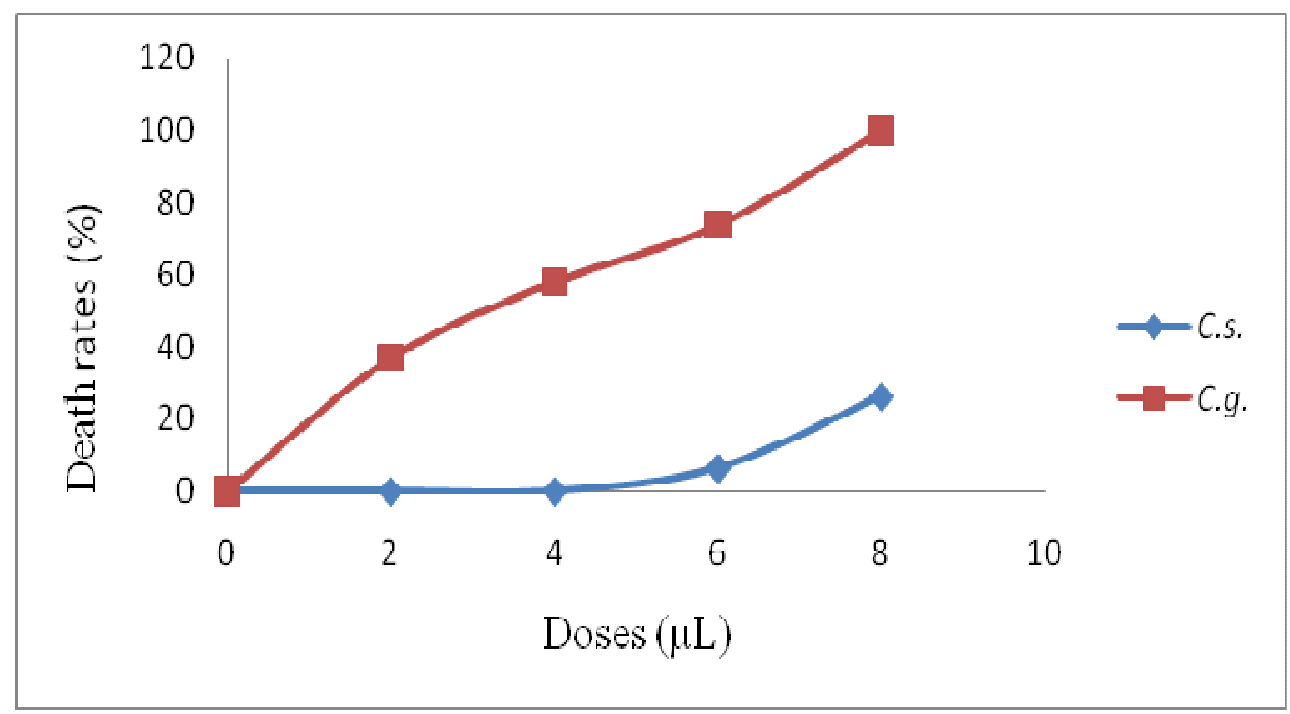

C. g.: Cymbopogon giganteus; C.s.: Cymbopogon schoenanthus.

Figure 1: Evolution of the death rates according to the essential oils amount of $C$. giganteus and $C$. schoenanthus. 
Table 1: Chemical composition of essential oils of leaves of Cymbopogon schoenanthus and Cymbopogon giganteus from Benin.

\begin{tabular}{|c|c|c|c|}
\hline \multirow[t]{2}{*}{$\mathbf{R I}$} & \multirow[t]{2}{*}{ Component } & \multicolumn{2}{|c|}{ Samples } \\
\hline & & C.s. $(\%)$ & C.g. (\%) \\
\hline 839 & 4-hydroxy-4-methyl-pentan-2-one & 0.1 & - \\
\hline 990 & dehydro-1,8-cineole & 0.1 & - \\
\hline 1000 & $\delta$-2-carene & 11.5 & - \\
\hline 1002 & Myrcene & - & 0.1 \\
\hline 1006 & $\alpha$-phellandrene & 0.2 & \\
\hline 1021 & p-cymene & 0.1 & 0.4 \\
\hline 1029 & limonene $+\beta$-phellandrene & 2.2 & 13.7 \\
\hline 1036 & (Z)- $\beta$-ocimene & 0.1 & - \\
\hline 1047 & (E)- $\beta$-ocimene & 0.1 & - \\
\hline 1081 & p-cymenene & - & 0.1 \\
\hline 1089 & fenchone & 0.1 & - \\
\hline 1092 & Nonanal & - & 0.1 \\
\hline 1105 & 1,3,8-p-menthatriene & - & 0.1 \\
\hline 1118 & trans-p-mentha-2,8-dien-1-ol & - & 16.4 \\
\hline 1126 & cis-menth-2-en-1-ol & 0.9 & - \\
\hline 1132 & cis-p-mentha-2,8-dien-1-ol & - & 9.5 \\
\hline 1138 & trans-epoxylimonene & - & 0.1 \\
\hline 1141 & Tetrahydroacetophenone & - & 0.4 \\
\hline 1145 & trans-menth-2-en-1-ol & 0.6 & - \\
\hline 1155 & 4-isopropenylcyclohex-2-enone & - & 1.2 \\
\hline 1170 & p-methylacetophenone & - & 0.3 \\
\hline 1174 & mentha-1,5-dien-8-ol & 1.3 & - \\
\hline \multirow[t]{2}{*}{1189} & 3,9-epoxymentha-1,8(10)-diene & - & 6.4 \\
\hline & trans-p-mentha-1(7),8-dien-2-ol & - & 0.3 \\
\hline 1193 & cis-dihydrocarvone & - & 6.4 \\
\hline 1198 & $\alpha$-terpineol & 1.3 & - \\
\hline 1199 & trans-isopiperitenol & - & 7.1 \\
\hline 1201 & trans-dihydrocarvone & - & 4.6 \\
\hline 1212 & trans-piperitol & 0.3 & - \\
\hline 1215 & cis-isopiperitenol & - & 5.9 \\
\hline 1217 & trans-carveol & - & 0.1 \\
\hline 1221 & nerol & 0.2 & - \\
\hline 1226 & p-mentha-1(7),8-dien-2-one & - & 0.1 \\
\hline 1229 & cis-p-mentha-1(7),8-dien-2-ol & - & 19.4 \\
\hline 1237 & cis-carveol & - & 2.9 \\
\hline 1244 & carvone & - & 0.5 \\
\hline 1247 & carvotanacetone & 0.1 & - \\
\hline 1250 & eucarvone & 0.3 & - \\
\hline 1265 & piperitone & 68.4 & - \\
\hline 1267 & hexanoate d'isoamyle & - & 0.2 \\
\hline 1270 & isopiperitenone & - & 0.2 \\
\hline
\end{tabular}


1272

1392

1424

1468

1485

1493

1512

1516

1520

1552

1587

1646

1646

1662 perillaldehyde

$\beta$-elemene

$\beta$-caryophyllene

octanoate d'isoamyle

germacrene-D

$\beta$-selinene

germacrene-A + cuparene

$\gamma$-cadinene

$\delta$-cadinene

elemol

oxyde de caryophyllene

$\gamma$-eudesmol

epi- $\alpha$-cadinol

$\alpha$-eudesmol

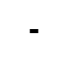

0.3

0.1

-

0.1

0.1

0.1

0.1

0.2

3.9

0.4

0.3

0.2

4.6

2.6

82.7

1.2

10.4

0.1

-

98.3
1.8

$-$

0.4

Oxygenated monoterpenes

Sesquiterpenes hydrocarbons

Oxygenated sesquiterpenes

Others compounds

Aromatics compounds and of derivatives

Total
14.4

80.6

0.7

0.7

95.3

- $\quad$ : not deternined

$\mathrm{RI}^{*}$, Retention index relative to n-alkanes $\left(\mathrm{C}_{9}-\mathrm{C}_{20}\right)$ on a DB1 capillary column ( $100 \%$ dimethylpolysiloxane);

Identification methods:

- GC, identification based on retention times of authentic compounds

- $\quad$ MS, identification based on computer matching of the mass spectra of peaks with NBS75K.L, NIST98.L libraries and published data (Adams, 2007; Joulain et König, 1998).

- $\quad \mathrm{RI}^{*}$, tentative identification based on comparison of retention index of the compounds with published data (Adams, 2007; Joulain et König, 1998).

C.s.: Cymbopogon schoenanthus

C.g. : Cymbopogon giganteus

Table 2: Antimicrobial activities of essential oils of the leaves of $C$. giganteus and C. schoenanthus.

\begin{tabular}{|c|c|c|c|c|}
\hline \multirow[b]{3}{*}{ Microbial stocks } & \multirow{2}{*}{\multicolumn{2}{|c|}{$\begin{array}{c}\text { Minimum Inhibitory } \\
\text { Concentration (MIC) }(\mathrm{mg} / \mathrm{mL})\end{array}$}} & \multirow{2}{*}{\multicolumn{2}{|c|}{$\begin{array}{c}\text { Minimum Bactericide } \\
\text { Concentration }(\mathrm{MBC})(\mathrm{mg} / \mathrm{mL})\end{array}$}} \\
\hline & & & & \\
\hline & $\begin{array}{c}C . \\
\text { giganteus }\end{array}$ & $\begin{array}{c}\text { C. } \\
\text { schoenanthus }\end{array}$ & $\begin{array}{c}C . \\
\text { giganteus }\end{array}$ & $\begin{array}{c}\text { C. } \\
\text { schoenanthus }\end{array}$ \\
\hline $\begin{array}{l}\text { Escherichia coli ATCC } \\
25922\end{array}$ & $0.64 \pm 0.34$ & $2.63 \pm 0.16$ & $2.56 \pm 0.15$ & - \\
\hline $\begin{array}{l}\text { Staphylococcus aureus } \\
\text { ATCC } 25923\end{array}$ & $0.32 \pm 0.02$ & $2.63 \pm 0.16$ & $1.32 \pm 0.08$ & - \\
\hline
\end{tabular}




\section{Conclusion}

The aim of this work was to study the chemical composition, antimicrobial and acaricide activities of the essential of $C$. giganteus and $C$. schoenanthus from Benin. The oils obtained from leaves by hydrodistillation were analysed by gas chromatography (GC) and gas chromatography-mass spectrometry (GC/MS). The total compounds accounted for about 95.3 $\%$ for the oil of C. giganteus and $98.3 \%$ for the oil of $C$. schoenanthus. The essential oils extracts reveal a very important in vitro activity on the studied strains, confirmed by Minimum Inhibitory Concentration (MIC) ranging from 0.32 to $0.64 \mathrm{mg} / \mathrm{mL}$ for $C$. giganteus and $2.63 \mathrm{mg} / \mathrm{mL}$ for $C$. schoenanthus. The oils $C$. giganteus could be recommended like active principle in formulations (creams, lotions, etc...) against the ectoparasites of the domestic ruminants.

\section{REFERENCES}

Abbott WS. 1925. A method for computing the effectiveness of an insecticide Journal of Ecological Entemology, 18: 265-267.

Adams RP. 2007. Identification of Essential oil Components by Gas Chromatography/Mass Spectrometry, $\left(4^{\text {th }}\right.$ edn). Allured Publishing Corporation Carol Stream. IL.

Akoègninou A, Van der Burg WJ, Van der Maesen LJG. 2006. Flore Analytique du Bénin. Backhuys Publishers; 1034p

Alitonou GA. 2006. Huiles essentielles extraites de plantes aromatiques acclimatées au Bénin: étude chimique, évaluation biologique et applications potentielles. Thèse de doctorat des Universités d'Abomey-Calavi, Bénin et Montpellier II, France.

Alitonou GA, Avlessi F, Sohounhloue DK, Agnaniet $\mathrm{H}$, Bessière JM, Menut $\mathrm{C}$. 2006. Investigations on the essential oil of Cymbopogon giganteus from Benin for its potential use as an anti- inflammatory agent, Int. J. Aromatherapy, 16: 37-41.

Bassolé IHN, Lamien-Meda A, Bayala B, Obame LC, Ilboudo AJ, Franz C, Novak J, Nebié RC, Dicko MH. 2011. Chemical composition and antimicrobial activity of Cymbopogon citratus and Cymbopogon giganteus essential oils alone and in combination. Phytomedecine, 18(12): 1070-1074.

Bouchikhi Tani Z, Bendahou M, et Khelil MA. 2010. Lutte contre la bruche Acanthoscelides obtectus et la mite Tineola bisselliella par les huiles essentielles extraites de deux plantes aromatiques d'Algerie. Lebanese Science Journal, 11(1): 55-68.

Fortin D, Lo M, Mayart G. 1990. Plantes Médicinales du Sahel, 55 Monographies des Plantes Utiles pour les Soins de Santé Primaires. CECI/ENDA; 280.

Joulain D, König WA. 1998. The Atlas of Spectral Data Sesquiterpene Hydrocarbons. E B Verlag: Hamburg.

Kanko C, Sawaliho BEl-H, Kone S, Koukoua G, N'guessan TY. 2004. Study of physicochemical properties of essential oils from Lippia multiflora, Cymbopogon citratus, Cymbopogon nardus, Cymbopogon giganteus. C. R. Chimie, 7(10-11): 1039-1042.

Ketoh GK., Koumaglo HK, Glitho IA, Huignard J. 2006. Comparative effect of Cymbopogon schoenantus essential oil and pipéritone on Callosobruchus maculatus development, Fitoterapia, 77: 506-510.

Kimbi HK, Fagbenro-Beyiokou AF. 1996. Efficacy of Cymbopogon giganteus and Enantia chlorantha against chloroquine resistant Plasmodium yoelii nigeriensis. East Afric. Med. J., 73(10): 636-637.

Koba K, Sanda K, Raymaud C, Mandin D, Millet J, Chaumont JP. 2003. Activité antimicrobienne des huiles essentielles de Cymbopogon citratratus L. (DC) staff ; Cymbopogon nardus L. Rendle et Cymbopogon schoenantus L. spreng. 
Journal de Mycologie Médicale, 13(4): 175-180.

Kpadonou KBGH, Yayi LE, Kpoviessi DSS, Gbaguidi F, Yèhouénou B, QuetinLeclercq J, Figueredo G, Moudachirou M, Accrombessi GC. 2012. Chemical variation of essential oil constituents of Ocimum gratissimum L. from Benin, and Impact on antimicrobial Properties and Toxicity against Artemia salina LEACH. Chem. Biodivers., 9: 139-150.

Menut C, Bessière JM, Samata D, Djibo AK, Buchbauer G, Schopper B. 2000. Aromatic plants of Tropical West Africa XI. Chemical composition, antioxidant and antiradical properties of the essential oils of three Cymbopogon species from Burkina Faso, J. Essent. Oils Res., 12: 207-212.

Nyamador WS, Ketoh GK, Amévoin K, Nuto Y, Koumaglo HK, Glitoh IA. 2010. Variation in the susceptibility of two Callosobruchus species to essential oil, Journal of Stored Products Research, 46: $48-51$.

Oussou KR, Kanko C, Guessend N, Yolou S, Koukoua G, Dosso M, N'guessan YT, Figueredo G, Chalchat J-C. 2004. Activités antibactériennes des huiles essentielles de trois plantes de Côte d'Ivoire. C.R. Chim., 7: 1081-1086.

Pamo TE, Tapondjou L, Tendonkeng F, Nzogang JF, Djoukeng J, Ngandeu F and Kana JR. 2003. Effet des huiles essentielles des feuilles et des extrémités fleuries de Cupressus lusitanica sur la tique (Rhipicephalus lunulatus) à l'Ouest-Cameroun. Revue de l'Académie des Sciences du Cameroun, 3(3): 169175.

Sahouo BG, Tonzibo ZF, Boti B, Chopa C, Mahy JP, N'guessan YT. 2003. Antiinflammatory and analgesic activities: chemical constituents of essential oils of Ocimum gratissimum, Eucalyptus citriodora and Cymbopogon giganteus inhibited lipoxygenase L-1 and cyclooxygenase of PGHS. Bull. Chem. Soc. Ethiopia, 12: 173-176.

Sidibé L, Chalchat JC, Garry RP, Lacombe L. 2001. Aromatic Plants of Mali (IV): Chemical composition of essential oils of Cymbopogon citratus (DC) Stapf and Cymbopogon giganteus (Hochst) Chiov. J. Essent. Oil Res., 13: 110-112.

Walker JB, Keirans JE, Horak IG. 2002. The Genus Rhipicephalus (Acari, Ixodidae): a Guide to the Brown Ticks of the World. Cambridge University Press: London; $655 \mathrm{p}$.

Yehouenou B, Wotto DV, Sessou Ph, Noudogbessi JP, Sohounhloue DCK. 2010a. Chemical study and antimicrobial activities of volatile extracts from fresh leaves of Crassocephalum rubens (Juss and Jack.) S. More against food borne pathogens. Scientific Study and Research, 11(3): 343-351.

Yèhouenou B, Noudogbèssi JP, Sessou P, Avlessi F, Sohounhloué D. 2010b. Etude chimique et activités antimicrobiennes d'extraits volatils des feuilles et fruits de Xylopia aethiopica (DUNAL) A. Rich. contre les pathogènes des denrées alimentaires. J. Soc. Ouest - Afr. Chim., 029: 19-27. 